------ Raf. J. Sci., Vol. 27, No.1, pp. 15-28, 2018------

\title{
Synthesis and Spectral Characterization of a New Series of N-4-Chlorobenzamide-5- phenylthiazolidin-3-one
}

\author{
Kezhal M. Salih \\ Hashim J. Azeez \\ College of Education/ Hawler Medical University/ College of Pharmacy/ University of Salahaddin/ \\ Erbil/ Iraq \\ Erbil/ Iraq
}

(Received 23/ 7 / 2013 ; Accepted 24 / 2 / 2014)

\begin{abstract}
A new series of 4-thiazolidinones (4a-j) has been synthesized by cyclocondensation of various acid hydrazones with thioglycolic acid. The intermediate hydrazones (3a-j) were synthesized by the condensation of various substituted benzaldehydes with 4-chlorobenzohydrazide (2). The starting compound 4-chlorobenzohydrazide was prepared from the reaction of ethyl 4-chlorobenzoate and hydrazine hydrate. The structures of the new synthesized compounds had been confirmed by spectral data (FTIR, PP ${ }^{1} \mathrm{H}-\mathrm{NMR},{ }^{13} \mathrm{C}-\mathrm{NMR}$, and ${ }^{13} \mathrm{C}-\mathrm{NMR}$-DEPT and ESIMS). Some of the synthesized compounds (4a-j) were evaluated for their antibacterial activity against Gram-positive bacteria staphylococcus aureus and Gram - negative psedomonas aeruginosa
\end{abstract}

Keywords: Acid hydrazone, 4-Thiazolidinone.

\section{تحضير و تشخيصطيف لملسلة جينة من مركبلت \\ N-4-Chlorobenzamide-5- phenylthiazolidin-3-one}

تضمن هذا البهث تحضيرسلسلة جديلة من مركبك الثايازولونينون(a-j) 4 من تقاعل الغلق الحلقي لسلسلة من مركبلت الهايدرازون الحلمضي مع م - ميركبتو حلمض الخليك. وقد م تحضير المركبلت الوسطية (a-j) من الفاعل التكثيفي لسلسلة

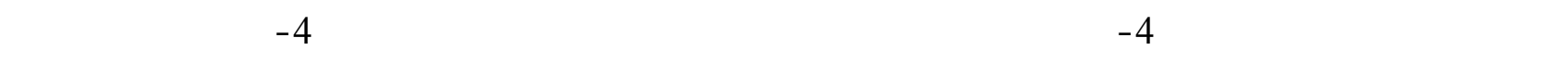
الهيدرازين المائي. كما قم تشخيص التركيب الكيميائي للمواد المحضرة بولنطة الطرائق الطيفية مل طيد ف الأثث عة تحد ت الحمراء FTIR والرنين النووي المغنلطيسي بأنواعه الثلاثة ESIMS staphylococcus aureus(+)

\section{INTRODUCTION}

Hydrazones have been demonstrated to possess antimicrobial, anticonvulsant, analgesic, antiinflammatory, antitubercular and antitumoral activities.

Acid hydrazones are not only intermediates, they are very effective organic compounds when used as intermediates in the synthesis of different biologically active compounds via different reagents. 4-Thiazolidinone is the most important product when acid hydrazones react with thioglycolic acid and thialactic acid (Rollas and Küçükgüzel, 2007). Thiazolidinones are the derivatives of thiazolidine, which belong to an important group of heterocyclic compounds containing sulfur and nitrogen in a five membered ring. 4-Thiazolidinones are derivatives of thiazolidine with a carbonyl group at the position (4)(I). Substitution is possible at 2,3 and 5 position(II,III), (Singh et al., 1981), Verna and Saraf, 2008). 


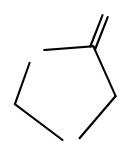

I

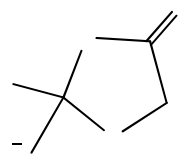

II

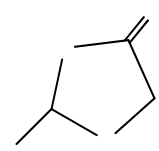

III

$\mathrm{X}=\mathrm{O}, \mathrm{S}, \mathrm{NR}, \mathrm{NN}=\mathrm{CR}, \mathrm{R}^{\prime}$

Many research on thiazolidinones has been carried out in the past. Various optical and geometrical isomers were reported in some works. Several methods for synthesis are available in the literature, (Tatar et al., 2008), which involve conventional, either one pot three component condensation or two step process synthesis, and microwave as well as combinational synthetic methods, (Rao et al., 2004), Sanghani et al., 2008). 4-Thiazolidinone derivatives are reported t $\mathbb{R}$ show a variety of biological activities depending on the substituents2Thiazolidin-4-ores can induce different pharmacological properties (Singh et al., 1981), Abhinit et al., 2009), such as antibacterial, antifungal, antidiabetic, anticonvulsant activities, cyclooxygenase and lipoxygenase inhibitory, (Tatar et a., (2008), Satetigeri et al., 2005), Rawal and Kumar (2006)).The synthesis of 4thiazolidinone derivatives used as antibiotic to combat resistant organisms which inhibit many steps in cell wall synthesis, peptidoglycan is an essential component of the cell wall of both Grampositive and Gram-negative bacteria (Silver, 2003; Andres et al., 2000) and tested for their ability of inhibition of the bacterial enzyme Murb. (Nagarajan et al., 2009).

\section{MATERIALS AND METHODS}

Melting points were determined by a capillary method on an elecrothermal melting point apparatus.IR were recorded on a thermo mattson IR 300 spectrophotometer as $\mathrm{KBr}$ disk and Biorad Merlin FTIR spectrophotometer Mod FTS 3000. The ${ }^{1} \mathrm{H}-\mathrm{NMR}$ and ${ }^{13} \mathrm{C}-\mathrm{NMR}$ spectra were measured with a Brucker $\left(300 \mathrm{MH}_{\mathrm{Z}}\right)$ spectrometer in DMSO- $\mathrm{d}_{6}$ at Al-Albayt University-Jordan. Mass spectra were recorded on High resolution mass Bruker Daltonics Data Analysis 3.4, and the GC-MS(EI),Shimatzu.by using ESI(+)/ ESI(-) method(where ESI=Electron Spray Ionization) at AlAlbayt University-Jordan. Chemical reagents used in the synthesis were purchased from Riedel-De haen AG, Scharlau and Fluka Company.

Thin layer chromatography (TLC) was carried out using DC-Aloufoline 20 x 20 Kieseigel 60 F 254 pre-coated Germany Merck.

\section{EXPERIMENTAL}

1. Synthesis of ethyl 4-chlorobenzoate, (Jasim et al., (2008), Williamson (1964)).

The ester was prepared by refluxing a mixture of $(0.1$ mole $)$ of 4 -chlorobenzoic acid and $(25 \mathrm{ml})$ absolute ethanol in the presence of $3-4 \mathrm{ml}$ concentrated sulfuric acid for $5 \mathrm{hrs}$.

2. Synthesis of 4- chlorobenzohydrazide, (Ali (2007)).

To a solution of ( $9.225 \mathrm{~g}, 0.05 \mathrm{~mole})$ of ethyl 4-chlorobenzoate in $10 \mathrm{ml}$ of ethanol a $(5 \mathrm{ml}$, 0.1 mole) of hydrazine hydrate was added and the mixture was refluxed for $2 \mathrm{hrs}$, then left to cool at room temperature to give white needle precipitate, which was filtered off, washed with cold ethanol and dried recrystallized from mixture ethanol/ water 3:1 (m.p 158-160C $\mathrm{C}^{\circ}$, yield 90\%).

3. Synthesis of $\mathbf{N}$-Substituted benzylidine- 4-chlorobenzohydrazide (3a-j), (Jasim et al., 2008)).

To a solution of ( $1.705 \mathrm{~g}, 0.01$ mole) 4- chlorobenzohydrazide in $20 \mathrm{ml}$ absolute ethanol, ( 0.01 mole) of substituted benzaldehyde was added followed by addition of some drops of glacial acetic acid, the reaction mixture was refluxed on a water bath for two hrs. Cooled, filtered off recrystallized from absolute ethanol. The physical properties with percentage of yield were listed in Table (2). 
4. Synthesis of N-4-Chlorobenzamide-2-(Substituted phenyl) 4-thiazolidinone3-yl(4a-j), (Shah and Desia, 2007; Verna and Saraf, 2008).

To a solution of compounds $(3-\mathrm{a}-\mathrm{j})(0.005 \mathrm{~mol})$ in $30 \mathrm{ml}$ benzene, $(0.006$, mol $)$ of thioglycolic acid was added slowly with stirring. The mixture was refluxed for 28 hours. The solvent removed under vacuum, and the reaction mixture was neutralized with cold saturated of sodium bicarbonate solution, the product was kept at room temperature for 24 hours. The formed products were filtered off, washed three times with distilled water, and recrystallized from the appropriate solvent to give the desired compounds. Percentage of yields and the physical properties of the synthesized thiazolidinone derivatives were listed in Table (3).

\section{RESULTS AND DISCUSSION}

The synthetic pathway followed in the preparation of the compounds was outlined in scheme (1). The starting material ethyl 4-chlorobenzoiate (1) was obtained by previously described method $^{\mathrm{PP},}$ (Jasim et al., 2008), Williamson (1964)).

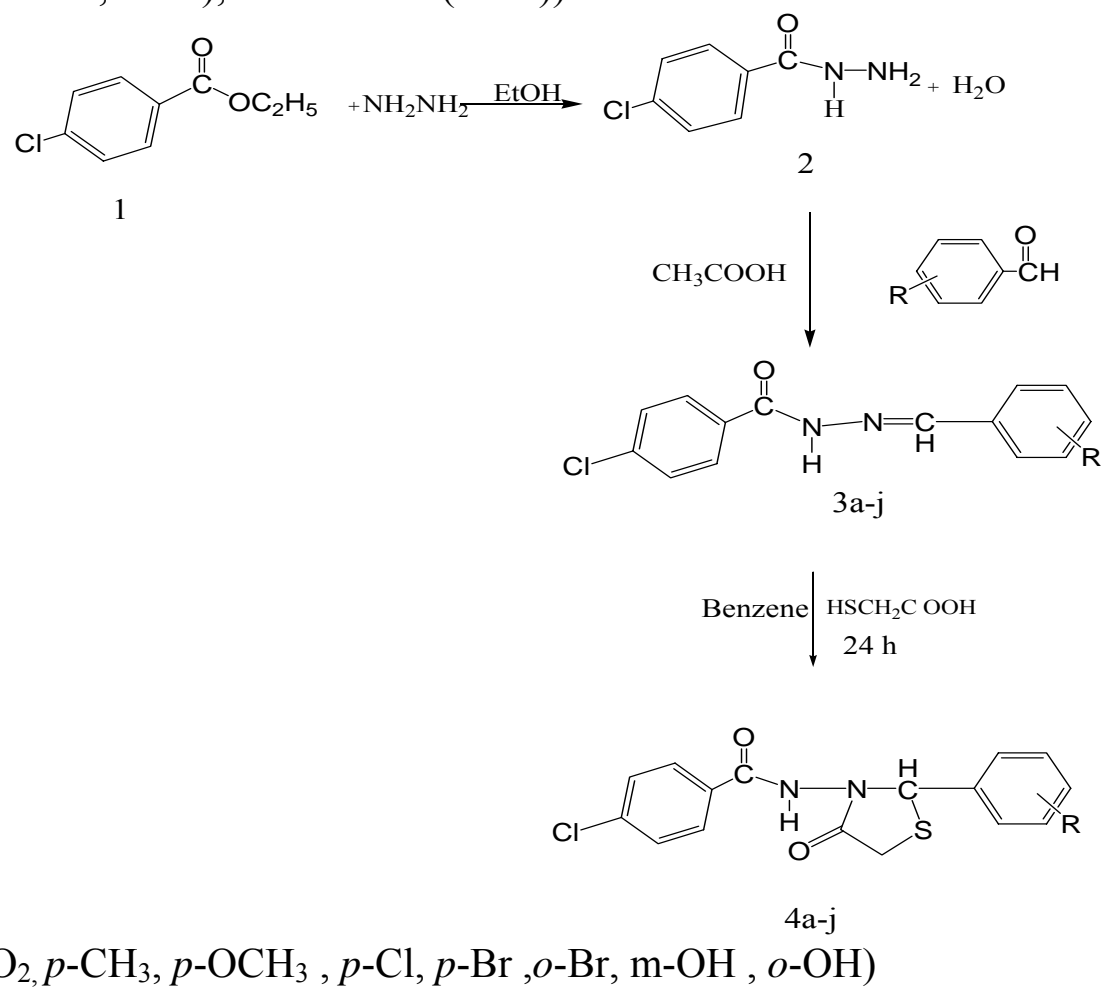

Scheme (1): Synthetic pathway for the preparation of $4(a-j)$

The versality of the reaction is well demonstrated by the fact that a variety of aryl aldehydes with electron-releasing and withdrawing substituents afforded their corresponding compounds $4 \mathrm{a}-\mathrm{j}$ in a good yields. The structures of all the newly synthesized compounds were confirmed by elemental analysis, IR, ${ }^{1} \mathrm{H}-\mathrm{NMR},{ }^{13} \mathrm{C}-\mathrm{NMR}$ and $\mathrm{MS}$ spectral and by their physical properties, (Tables 2- 9).

Compound (2) was also characterized by IR spectrum, ${ }^{1} \mathrm{H}-\mathrm{NMR}$ and ${ }^{13} \mathrm{C}-\mathrm{NMR}$ data. Its IR spectrum showed the appearance of new three bands at 3308- $3192 \mathrm{~cm}^{-1}$ with the two bands of amide (I) and amide (II) at 1667 and 1616 respectively which indicated the formation of the product. 4- Chlorobenzohydrazide was also identified by the ${ }^{1} \mathrm{H}-\mathrm{NMR}$ through the appearance of one proton at $\delta(10) \mathrm{ppm}$ and a singlet of two protons at $\delta(4.5) \mathrm{ppm}$ which belongs to both $\mathrm{NH}$ and $\mathrm{NH}_{\mathrm{BB} 2}$ respectively (Patel and Patel (2010)). The presence of 4 protons as a two doublet at 7.5-7.8 ppm belong to the $\mathrm{p}$-disubstituted aromatic rings. 
The ${ }^{\mathrm{PP} 13} \mathrm{C}$-NMR spectrum of 4-chlorobenzo hydrazide four signals in the aromatic region and

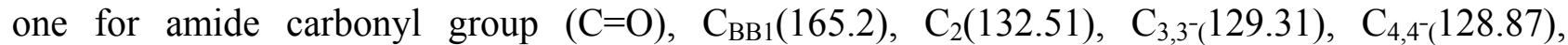
$\mathrm{C}_{5}(136.32) \mathrm{ppm}$. The disappearance of non protonated carbons $\mathrm{C}_{1}, \mathrm{C}_{2}, \mathrm{C}_{5}$ was very clear in ${ }^{13} \mathrm{C}$ NMR-DEPT spectrum, while the remaining protonated carbons were observed as a two signals at

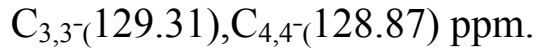

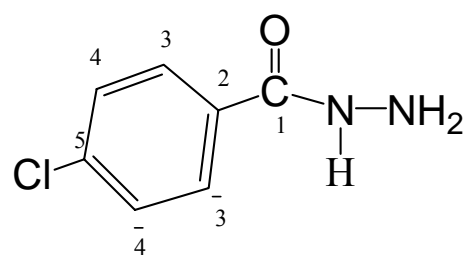

2

The structure of acid hydrazones derivatives (3a-j) were also assigned on the bases of the analysis of spectral data, their IR spectrum showed the absence of stretching vibration of amino group of compound (2) with observation of new bands due to the stretching vibration of characteristic azomethine bond $\mathrm{C}-\mathrm{H}, \mathrm{HC}=\mathrm{N}$ and $\mathrm{C}=\mathrm{O}$ at $\left(2838-2890 \mathrm{~cm}^{\mathrm{PP}-1}\right),(1594-1639) \mathrm{cm}^{-1}$ (1644-1677) $\mathrm{cm}^{-1}$ respectively, and observation of new bands due to aromatic $\mathrm{CH}$ str. at (3024$3085) \mathrm{cm}^{-1}$, and $\mathrm{C}=\mathrm{C}$ str. at $\left(1549-1607 \mathrm{~cm}^{-1}\right.$ ) (Table 4) (Küçükgüzel et al., 2006; Pate and Shaik ,2010 ), Fig.(1). Moreover ${ }^{1} \mathrm{H}-\mathrm{NMR}$ Spectra showed clear changes in splitting pattern of aromatic region that showed multiple signals for 8 protons at $\delta(6.7-8.1) \mathrm{ppm}$ with two singlet at $\delta(8.3-8.6)$ ppm and at $\delta$ ( 10.8-12.2) ppm which attribute to $\mathrm{N}=\mathrm{CH}, \mathrm{CO}-\mathrm{NH}$ protons respectively Fig. (2) (3a), (Shah and Desia (2007), Palekar et al., 2009), Sharanabasappa et al., 2010), (Table 5).

The ${ }^{13} \mathrm{C}$-NMR of compounds (3a-j) provide evidence for the formation of acid hydrazones, the appearance of 8 signals due to aromatic carbons and a signal for azomethine carbon with one signal for amide carbonyl $\mathrm{C}=\mathrm{O}$, in the case of the aldehydic ring with substituent at para position, as in compounds $(3 \mathrm{a}, \mathrm{e})$ : showed 10 signal for 10 carbon with signals due to $4-\mathrm{OCH}_{3}$ and $4-\mathrm{CH}_{3}$ carbons at 55.7 and 21.48 respectively, Fig. (3). While in hydrazones substituted aldehydic ring at o-position exhibited 12 singlets for 12 carbons, (Table 6). From ${ }^{13} \mathrm{C}-\mathrm{NMR}$-DEPT spectrum the conversion of compound 2 to $3 \mathrm{a}-\mathrm{j}$ was proved from the absence of non-protonated carbons, the ${ }^{13} \mathrm{C}$ NMR-DEPT spectrum for example of compound (3a) showed six signals for six protonated carbon with odd number, $\mathrm{OCH}_{3}: 55.76, \mathrm{C}_{2,2^{-}}: 114.03, \mathrm{C}_{9,9^{-}}: 129.01, \mathrm{C}_{8,8^{-}}: 129.23, \mathrm{C}_{3,3^{-}}: 129.96, \mathrm{C}_{5}: 148.49$ with disappearance of $\mathrm{C}_{4}$ at $127.23, \mathrm{C}_{7}$ at $136.91, \mathrm{C}_{10} ; 136.91, \mathrm{C}_{6}: 162.33$ and $\mathrm{C}_{1}: 161.33 \mathrm{ppm}$, Fig. (4).

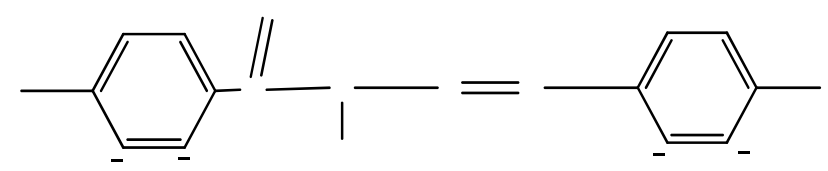

The molecular weight of some products was established by ESI mass spectrometer, the molecular weight of compound (3a) was obtained from the mass spectrum, Fig. (5), that determined by molecular ion $[\mathrm{M}+23]^{+\cdot}$ at $\mathrm{m} / \mathrm{z} 311(5.8 \%)$.

The IR spectra of compounds $4 \mathrm{~b}, 4 \mathrm{~d}$ showed two isomers of substituted 4-thiazolidinone and they are separated according of their $\mathrm{R}_{f}$ values using TLC aluminum silica gel plate using (Ethyl acetate: n-hexane 2:3). Formation of compounds $4 a-j$ were characterized from the physical properties and analytical data, the IR spectra of 4-thiazolidinones showed the characteristic str. vibration of $\mathrm{C}=\mathrm{O}$ bands in the region of $1667-1717 \mathrm{~cm}^{-1}$ (Shah and Desia , 2007), Palekar et al., 2009), Aydogan et al., 2001), with the absence of $C=N$ str. band Fig. (6), (Table 7). 
The ${ }^{1} \mathrm{H}-\mathrm{NMR}$ spectra also showed the characteristic signal for 4-thiazolidinone at $\delta(3.7-4.7)$ ppm as two doublet [while in some of the prepared compounds were observed as singlet], due to non equivalent geminal methylene protons assigned for $\mathrm{S}-\mathrm{CH}_{2}$ protons, (Shah and Desia (2007)), with a single signal at $\delta(6-6.7)$ attributed to $(\mathrm{C}-\mathrm{H})$ protons of the heterocyclic ring, while N-H amide exhibited at $\delta$ (8.3-12) Fig. (7), (Table 8).

The ${ }^{13} \mathrm{C}$-NMR spectra of this series showed 12 different carbons for thiazolidinone and substituted benzaldehyde in para position,14 different carbons in thiazolidinone with substituted benzaldehyde in ortho position, (Table 9). The formation of new compounds were supported by ${ }^{13} \mathrm{C}$ - NMR spectra with the appearance of a new signal due to carbon atoms which were absent in the ${ }^{13} \mathrm{C}$-NMR spectrum of the Schiff bases (disappearance of azomethines carbon), the carbons related to thiazolidinone moiety were observed at $\left(\mathrm{C}_{5}\right) \delta(66.7-61),\left(\mathrm{C}_{6}\right) \delta(29.7-38.4)$ and $\mathrm{C}=\mathrm{O}$ at (169-170) ppm respectively. The structure of 4-thiazolidinone derivatives were also established from their ${ }^{13}$-C-NMR-DEPT spectra, the disappearance of non protonated carbon atoms and appearance of carbons which have odd number of protons, and those bearing an even protons of thiazolidinone moiety observed at opposite side of the spectrum.<smiles>O=C(NN1C(=O)CSC1c1ccc(Cl)cc1)c1ccc(Cl)cc1</smiles>

$4 d$

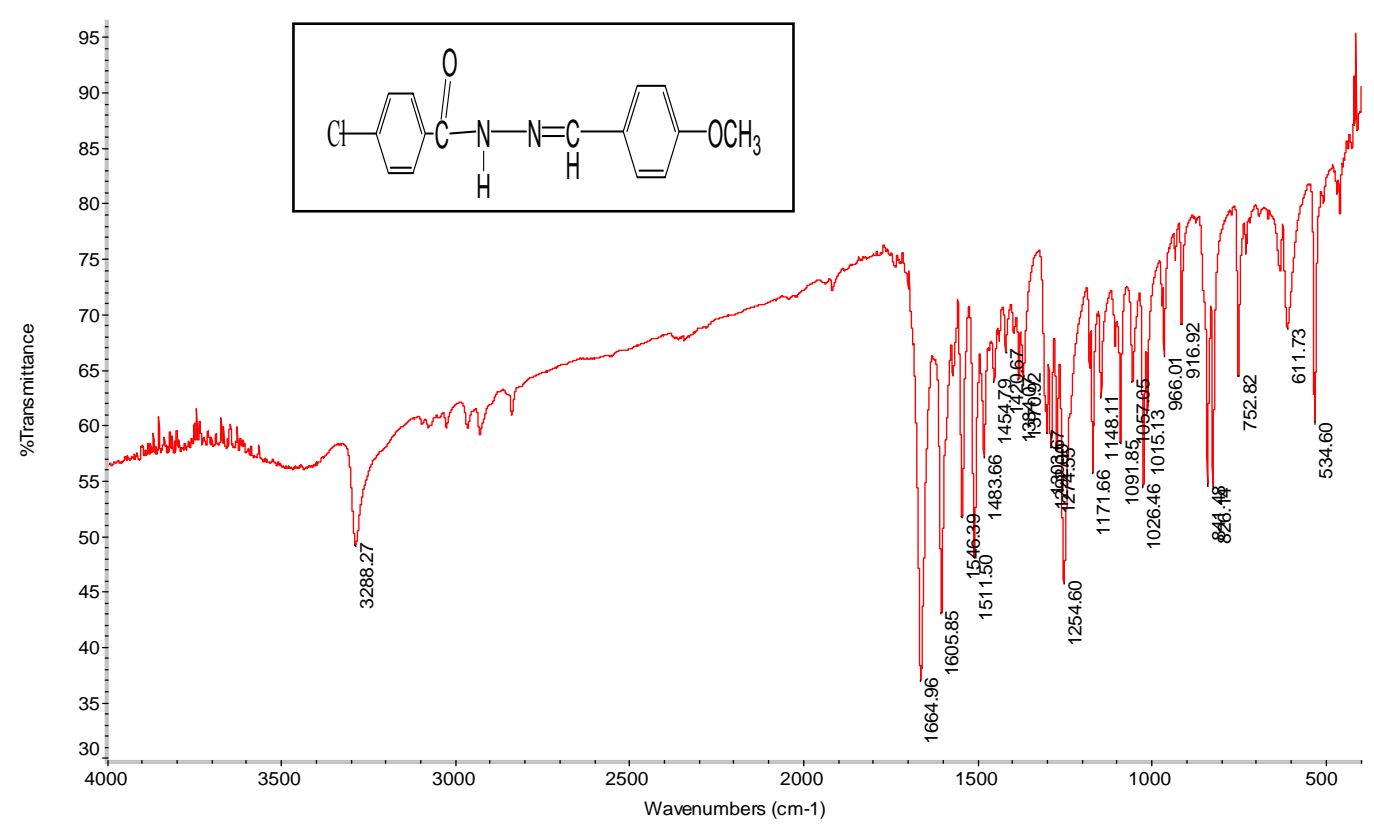

Fig. 1 : IR spectrum of compound (3a) 


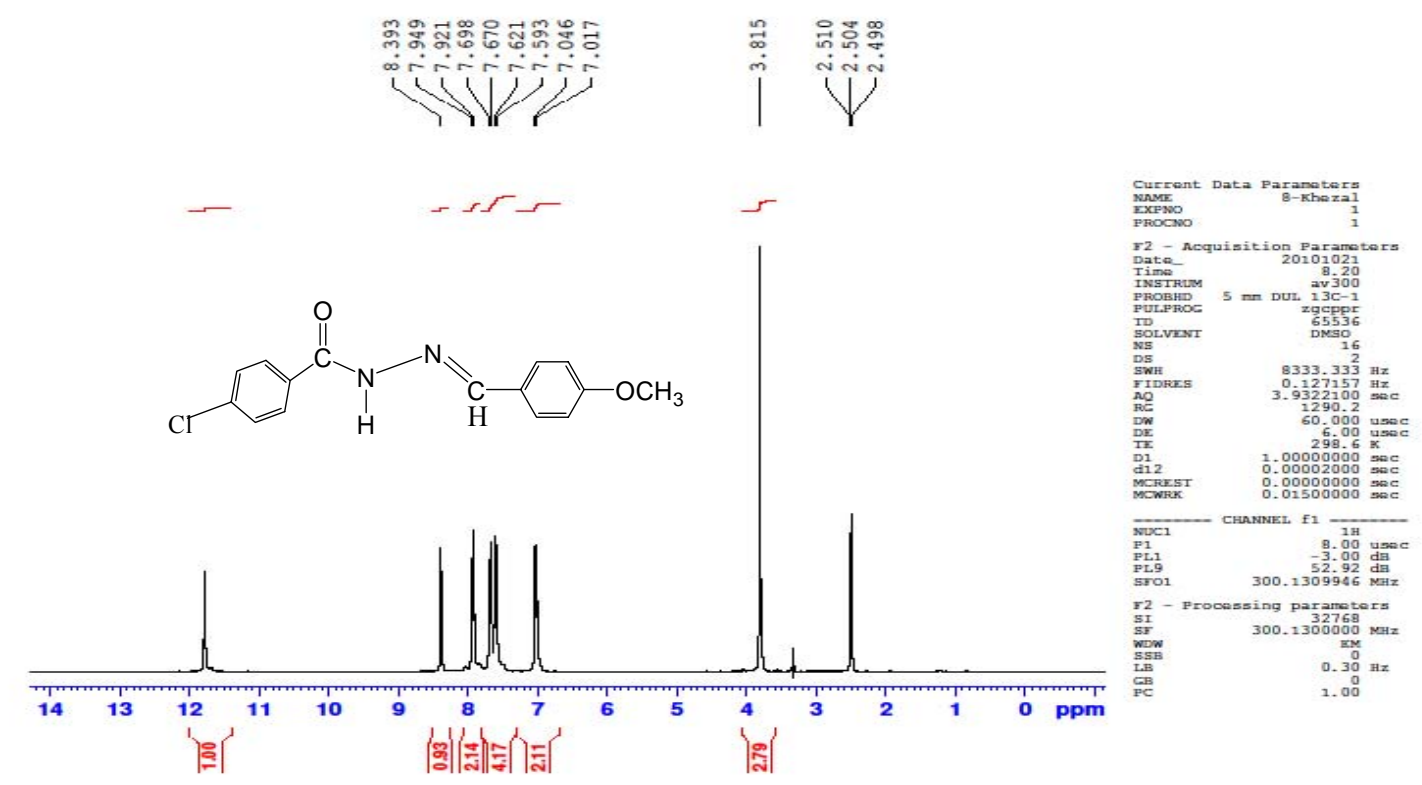

Fig. 2: 1H-NMR spectrum of compound (3a)
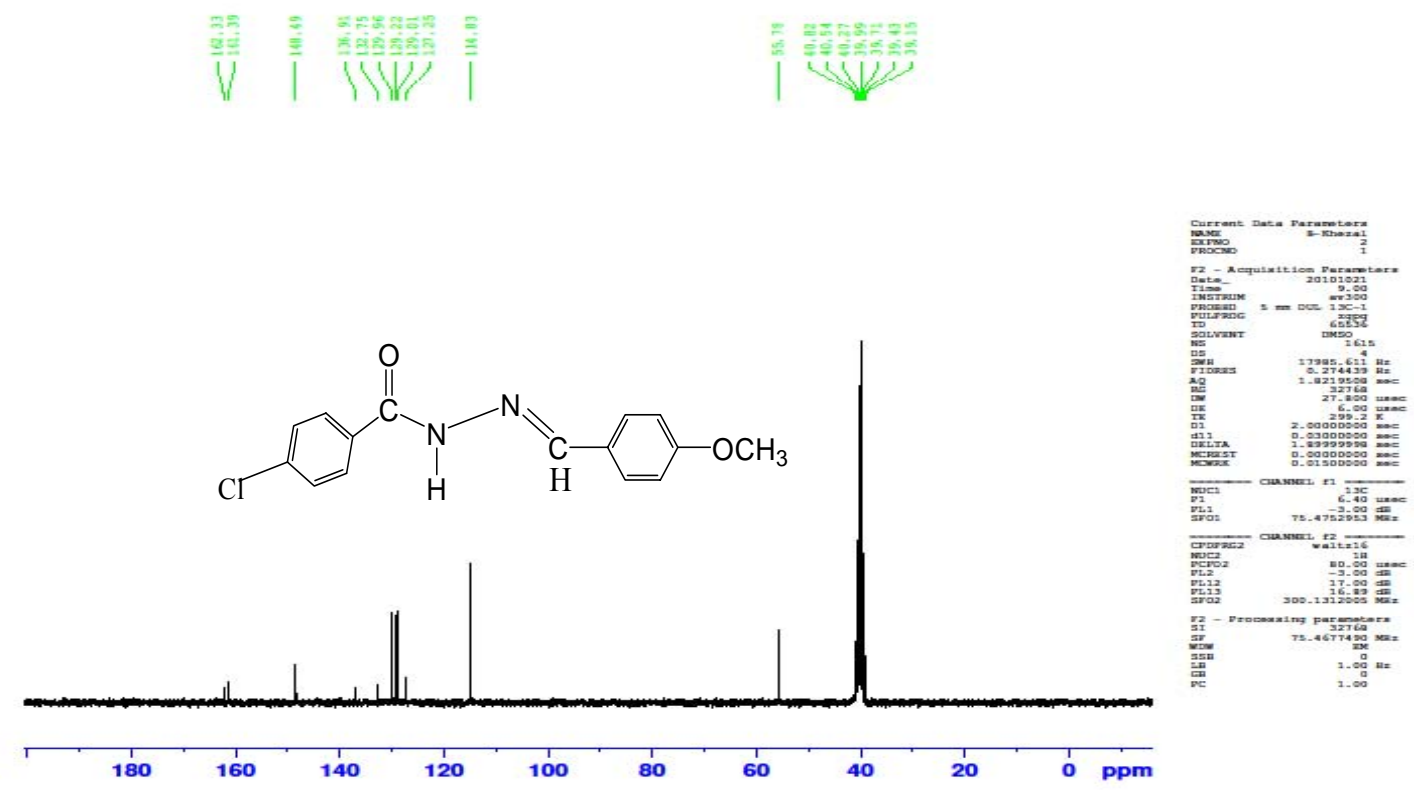

Fig. 3: ${ }^{13} \mathrm{C}-\mathrm{NMR}$ spectrum of compound (3a) 

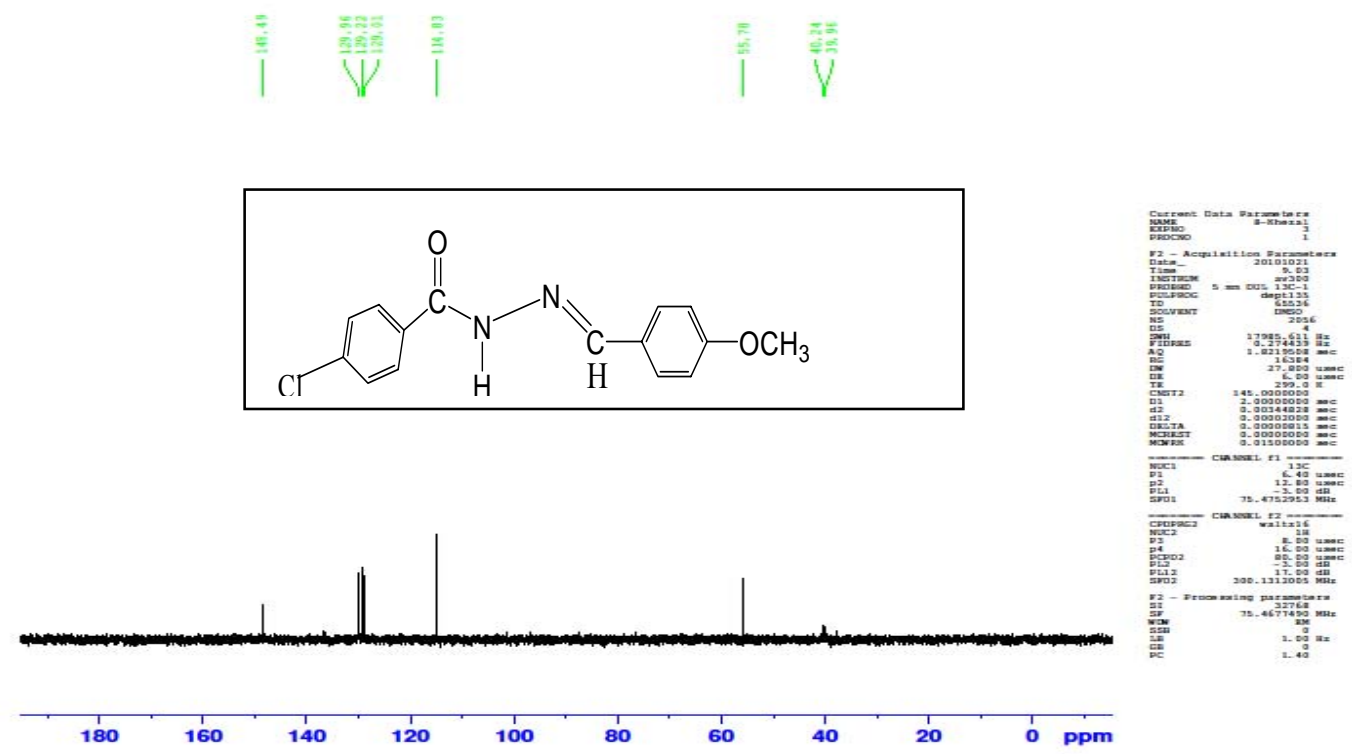

Fig. 4: Dept ${ }^{13} \mathrm{C}-\mathrm{NMR}$ spectrum of compound (3a)

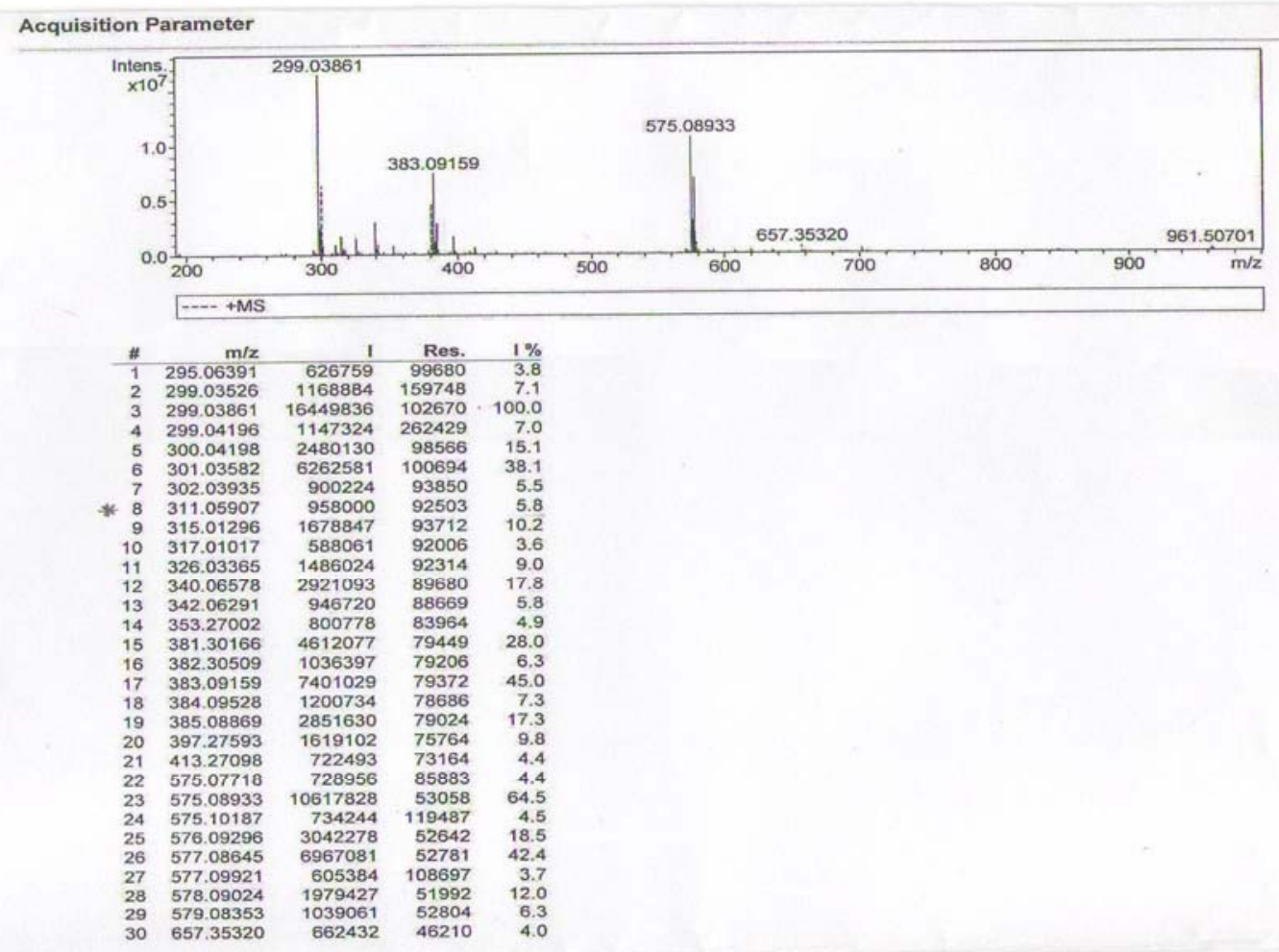

Fig. 5: Mass spectrum of compound (3a) 


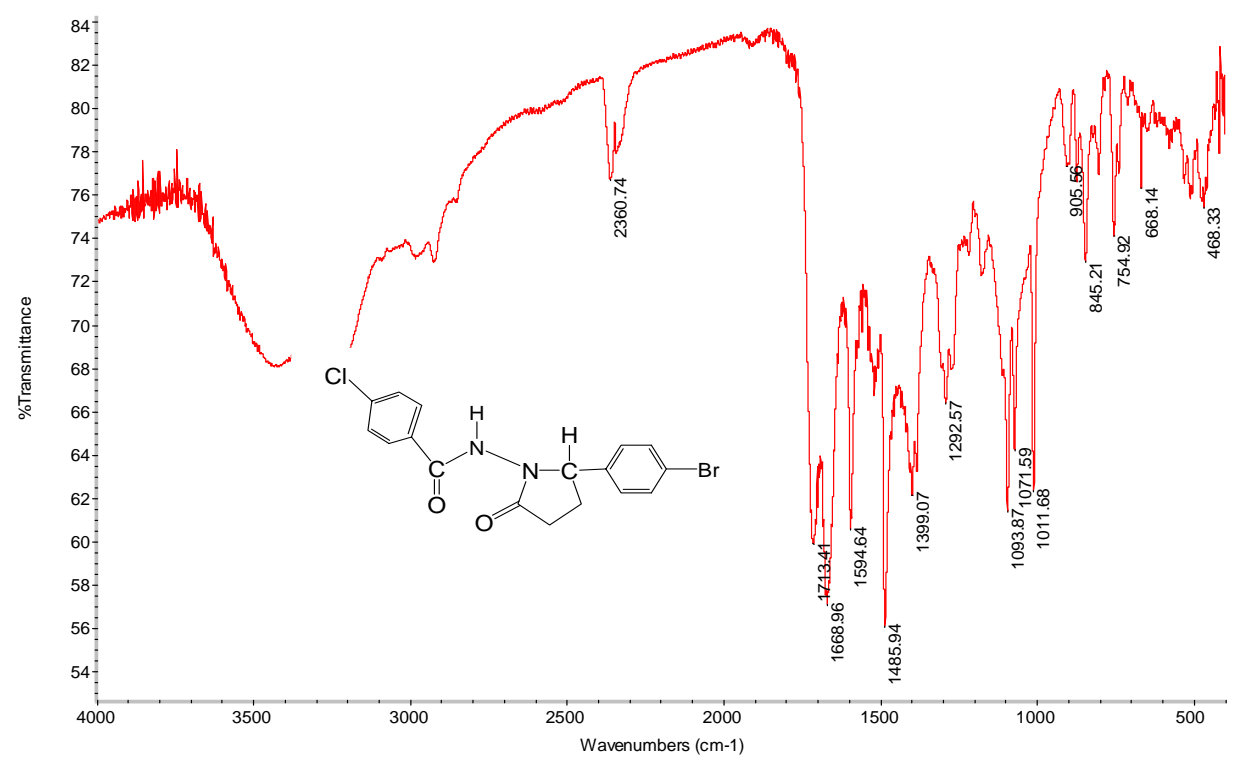

Fig. 6: IR spectrum of compound (4c)

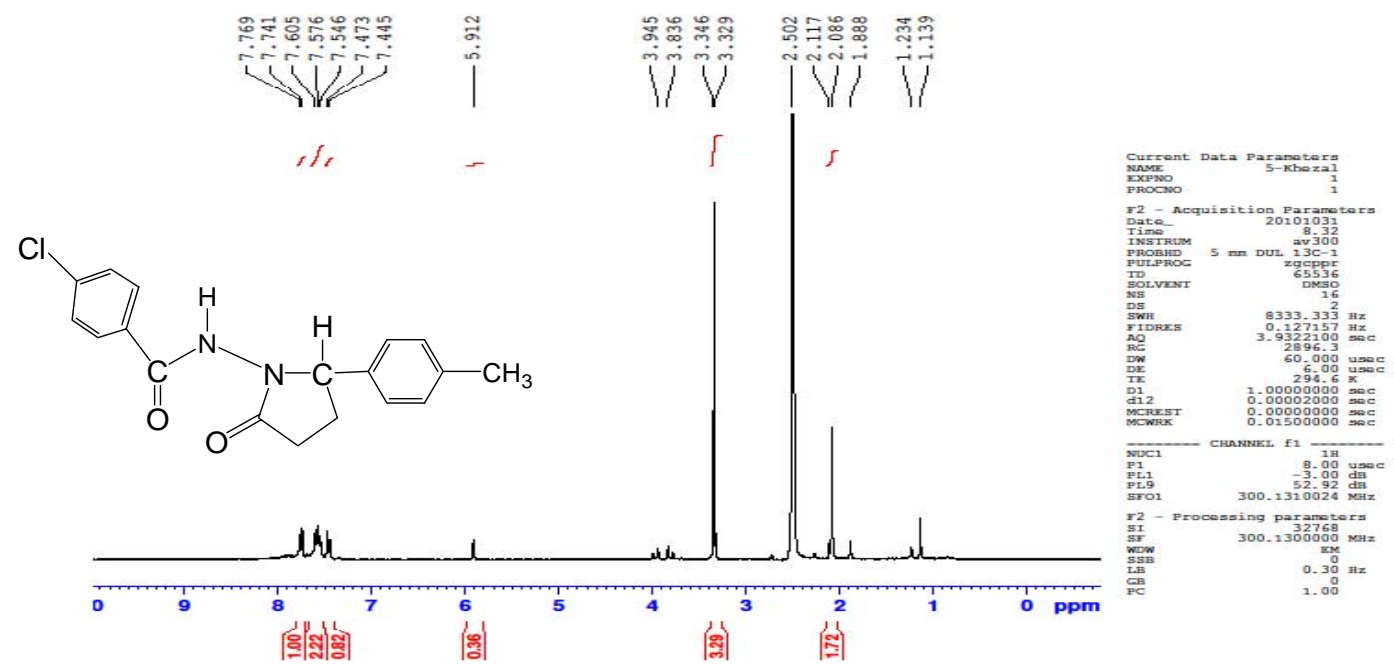

Fig. 7: ${ }^{1} \mathrm{H}-\mathrm{NMR}$ spectrum of compound (4 e)

BIOLOGICAL ACTIVITY

The antibacterial activities for some of the synthesized thiazolidinone derivatives were carried out using disk agar diffusion method and the antibacterial activity was determined by measuring the diameter of inhibition zone.

The investigation of antibacterial screening data (Table 1) revealed that compounds (4 a-j) have different activity against S.aureus $\mathrm{G}(+\mathrm{ve})$ and psedomonas aeruginosa $\mathrm{G}(-\mathrm{ve})$.

Compounds (4a, d, f) were showed higher sensitivity than the others against S.aureus $\mathrm{G}$ (+ve), it might be due to the substituent on the aromatic ring by substituent such as $-\mathrm{OCH}_{3},-\mathrm{NO}_{2}$ can form hydrogen bond with peptidoglycan causes inhibition of MurB enzyme which is an enzyme unique to prokaryotic cells. While they almost were active towards the psedomonas aeruginosa $\mathrm{G}$ (-ve )usually this type of bacteria has a high resistance against most of the drugs. 
Table 1: Sensitivity of Staphylococcus-aureus and pseudomonas aerginosa against some prepared thiazolidinones

\begin{tabular}{|c|c|c|}
\hline Compound & $\begin{array}{c}\text { S-aureus } \\
\text { G+ve }\end{array}$ & $\begin{array}{c}\text { Pseudomonas } \\
\text { aeruginosa } \\
\text { G-ve }\end{array}$ \\
\hline $4 \mathrm{a}$ & +++ & ++++ \\
\hline $4 \mathrm{c}$ & - & ++++ \\
\hline $4 \mathrm{~d}$ & ++++ & ++++ \\
\hline $4 \mathrm{e}$ & - & ++++ \\
\hline $4 \mathrm{f}$ & ++++ & ++++ \\
\hline $4 \mathrm{~g}$ & - & +++ \\
\hline
\end{tabular}

Key to symbols:

\begin{tabular}{|c|c|c|}
\hline High reactive & ++++ & (inhibition zone $24 \mathrm{~mm}$ ) \\
\hline Active & +++ & (inhibition zone $20-24 \mathrm{~mm}$ ) \\
\hline Moderately active & ++ & (inhibition zone $16-20 \mathrm{~mm}$ ) \\
\hline Slightly active & + & (inhibition zone $12-16 \mathrm{~mm}$ ) \\
\hline Inactive & - & (inhibition zone $12 \mathrm{~mm}$ ) \\
\hline
\end{tabular}

Table 2: Physical properties of the synthesized compounds (3a-j)

\begin{tabular}{|c|c|c|c|c|c|}
\hline 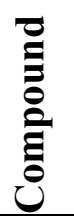 & $\mathbf{R}$ & Yield\% & M.P ${ }^{\circ} \mathbf{C}$ & Color & $\begin{array}{l}\mathrm{R}_{f} 40 \% \\
\text { Ethylacetate- } \\
\text { n-hexane }\end{array}$ \\
\hline $3 a$ & $4-\mathrm{OCH}_{3}$ & 82 & $179-180$ & Beige & 0.58 \\
\hline $3 b$ & $4-\mathrm{F}$ & 78 & $182-184$ & White & 0.6 \\
\hline $3 c$ & $2-\mathrm{Br}$ & 87 & $220-222$ & Beige & 0.746 \\
\hline $3 d$ & 4-Cl & 75 & $218-221$ & White & 0.47 \\
\hline $3 e$ & $4-\mathrm{CH}_{3}$ & 68 & $202-203$ & Chalky & 0.714 \\
\hline $3 \mathrm{f}$ & $4-\mathrm{NO}_{2}$ & 74 & $224-228$ & Yellow & 0.68 \\
\hline $3 g$ & $4-\mathrm{N}(\mathrm{CH} 3)_{2}$ & 82 & $184-185$ & Orange & 0.28 \\
\hline $3 \mathrm{~h}$ & 4-Br & 69 & $218-220$ & Beige & 0.43 \\
\hline $3 \mathrm{i}$ & $2-\mathrm{NO}_{2}$ & 68 & $210-212$ & Yellow & 0.62 \\
\hline $3 \mathrm{j}$ & $2-\mathrm{OH}$ & 78 & $204-206$ & Bright green & 0.48 \\
\hline
\end{tabular}


Table 3: Physical properties of the prepared thiazolidinone compounds (4a-j).

\begin{tabular}{|c|c|c|c|c|c|}
\hline 官 & $\mathbf{R}$ & $\frac{\partial^{\circ}}{\overbrace{0}^{e}}$ & M.P ${ }^{\circ} \mathbf{C}$ & Color & 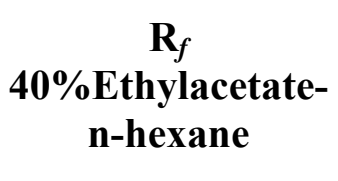 \\
\hline $4 a$ & $4-\mathrm{OCH}_{3}$ & 48 & $159-160$ & White & 0.85 \\
\hline $4 b$ & $4-\mathrm{F}$ & 62 & $\begin{array}{l}90-93 \\
97-98\end{array}$ & White & $\begin{array}{l}0.92 \\
0.79\end{array}$ \\
\hline $4 c$ & $2-\mathrm{Br}$ & 56 & $198-200$ & White & 0.46 \\
\hline $4 d$ & 4-Cl & 68 & $\begin{array}{l}206-208 \\
135-138\end{array}$ & White & $\begin{array}{c}0.88 \\
0.369\end{array}$ \\
\hline $4 \mathrm{e}$ & $4-\mathrm{CH}_{3}$ & 58 & 188-192 & White & 0.5 \\
\hline $4 f$ & $4-\mathrm{NO}_{2}$ & 65 & $202-204$ & Creamy & 0.76 \\
\hline $4 g$ & $4-\mathrm{N}\left(\mathrm{CH}_{3}\right)_{2}$ & 80 & $239-240$ & Green & 0.66 \\
\hline $4 \mathrm{~h}$ & $4-\mathrm{Br}$ & 58 & $221-224$ & Brown & 0.277 \\
\hline $4 i$ & $2-\mathrm{NO}_{2}$ & 58 & $218-220$ & Yellow & 0.56 \\
\hline $4 j$ & $2-\mathrm{OH}$ & 68 & $180-183$ & Green & 0.48 \\
\hline
\end{tabular}

Table 4: Assignment of characteristics frequencies $v\left(\mathrm{~cm}^{-1}\right)$ of I.R. spectra for the prepared compounds (3a-j):

\begin{tabular}{|c|c|c|c|c|c|c|c|c|c|}
\hline ن & $\simeq$ & $\frac{\pi}{z}$ & 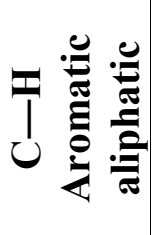 & 而兽 & 囟 & 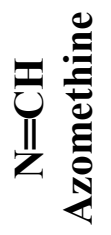 & $\bigcup_{U}$ & 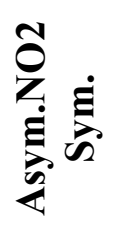 & $C-X$ \\
\hline $3 a$ & $\begin{array}{c}4- \\
\mathrm{OCH}_{3}\end{array}$ & 3287 & $\begin{array}{l}3024 \\
2964\end{array}$ & 2838 & 1664 & 1636 & 1606 & & $\begin{array}{c}748 \\
1256\end{array}$ \\
\hline $3 b$ & $4-F$ & 3194 & 3033 & 2845 & 1646 & 1603 & 1558 & & $\begin{array}{c}756 \\
1065\end{array}$ \\
\hline $3 c$ & $2-\mathrm{Br}$ & 3214 & 3052 & 2875 & 1651 & 1591 & 1549 & & $\begin{array}{l}514 \\
749\end{array}$ \\
\hline $3 d$ & $4-\mathrm{Cl}$ & 3230 & 3070 & 2875 & 1655 & 1596 & 1556 & & 713 \\
\hline $3 e$ & 4- $\mathrm{CH}_{3}$ & 3285 & $\begin{array}{l}3027 \\
2965\end{array}$ & 2875 & 1665 & 1635 & 1607 & & 750 \\
\hline $3 f$ & $4-\mathrm{NO}_{2}$ & 3275 & 3085 & 2880 & 1677 & 1642 & 1593 & $\begin{array}{l}1517 \\
1347\end{array}$ & 745 \\
\hline $3 g$ & $\begin{array}{c}4 \mathrm{~N}(\mathrm{CH} \\
3)_{2}\end{array}$ & 3175 & 2994 & 2880 & 1644 & 1611 & 1596 & & 755 \\
\hline $3 \mathrm{~h}$ & $4-\mathrm{Br}$ & 3250 & 3075 & 2800 & 1667 & 1639 & 1594 & & $\begin{array}{l}748 \\
514\end{array}$ \\
\hline $3 \mathrm{i}$ & $2-\mathrm{NO}_{2}$ & 3193 & 3066 & 2880 & 1652 & 1593 & 1550 & $\begin{array}{l}1519 \\
1341\end{array}$ & 747 \\
\hline $3 \mathrm{j}$ & $2-\mathrm{OH}$ & $\begin{array}{c}3215 \\
3376(\mathrm{OH})\end{array}$ & 3040 & 2890 & 1651 & 1623 & 1606 & & 743 \\
\hline
\end{tabular}

$\mathrm{X}=\mathrm{Cl}, \mathrm{Br}, \mathrm{F}, \mathrm{O}$ 
Table 5: ${ }^{1} \mathrm{H}-\mathrm{NMR}$ data (chemical shift $\delta$ ) of some prepared compounds (3a-j) in DMSO (d6)

\begin{tabular}{|c|c|c|c|c|c|}
\hline Compound & $\begin{array}{c}\text { N-H } \text { amide } \\
\text { ppm } \\
\text { s,1H }\end{array}$ & $\begin{array}{c}\mathbf{N}=\mathbf{C H} \\
\text { azomethin } \\
\text { ppm } \\
\mathbf{s , 1 H}\end{array}$ & $\begin{array}{c}\mathbf{C H} \\
\text { aromatic } \\
\mathbf{p p m} \\
\mathbf{m , 8 H}\end{array}$ & $\begin{array}{c}\mathrm{OCH}_{3} \\
\mathbf{p p m} \\
\text { s,3H }\end{array}$ & $\begin{array}{l}\mathrm{CH}_{3} \\
\text { ppm } \\
\text { s,3H }\end{array}$ \\
\hline $3 a$ & 11.8 & 8.39 & $7-7.9$ & 3.8 & \\
\hline $3 d$ & 12 & 8.4 & $7.5-7.9$ & & \\
\hline $3 e$ & 10.8 & 8.4 & $7.2-7.97$ & & 2.3 \\
\hline $3 f$ & 12.1 & 8.5 & $7.6-8.1$ & & \\
\hline $3 \mathrm{~g}$ & 11.8 & 8.3 & $6.7-7.9$ & & 2.97 \\
\hline $3 \mathrm{~h}$ & 12 & 8.45 & $7.5-7.97$ & & \\
\hline $3 \mathrm{i}$ & 12.2 & 8.6 & $7.6-8.1$ & & \\
\hline
\end{tabular}

Table 6: Chemical Shift $(\delta \mathrm{ppm}){ }^{13} \mathrm{C}-\mathrm{NMR}$ data for some prepared Hydrazide-Hydrazones (3 a-j) Solvent:DMSO d 6

\begin{tabular}{|c|l|l|l|l|c|}
\hline Compound & $\begin{array}{l}\mathbf{C H}_{3} \\
\text { ppm }\end{array}$ & $\begin{array}{l}\mathbf{O C H}_{3} \\
\mathbf{p p m}\end{array}$ & $\begin{array}{l}\mathbf{C}_{\text {aromatic }} \\
\mathbf{P p m}\end{array}$ & $\begin{array}{l}\mathbf{C}_{\text {azomethin }} \\
\text { Ppm }\end{array}$ & $\begin{array}{l}\mathbf{C}=\mathbf{O} \\
\mathbf{P p m}\end{array}$ \\
\hline $3 \mathrm{a}$ & & 55.78 & $114.83-161.39$ & 148.49 & 162.33 \\
\hline $3 \mathrm{~b}$ & & & $116.251-161.94$ & 147.44 & 165.278 \\
\hline $3 \mathrm{~d}$ & & & $129.04-137.124$ & 147.262 & 162.587 \\
\hline $3 \mathrm{e}$ & 21.479 & & $127.578-140.454$ & 148.695 & 162.471 \\
\hline $3 \mathrm{f}$ & & & $124.5-1488.4$ & 146.05 & 162.82 \\
\hline $3 \mathrm{~g}$ & 40.787 & & $112.256-152.031$ & 149.031 & 162.020 \\
\hline $3 \mathrm{i}$ & & & $125.128-148.731$ & 143.765 & 162.726 \\
\hline
\end{tabular}

Table 7: Assignment of characteristic frequencies v́ $\left(\mathrm{cm}^{-1}\right)$ of IR spectra for the synthesized 4thiazolidinone (4a-j)

\begin{tabular}{|c|c|c|c|c|c|}
\hline Compound & N-H & $\begin{array}{l}\mathrm{C}=\mathrm{O} \\
\text { cyclic }\end{array}$ & $\begin{array}{l}\mathrm{C}=\mathrm{O} \\
\text { amide }\end{array}$ & $\begin{array}{l}\mathrm{N}-\mathrm{H}_{\text {bend. }} \\
\mathrm{C}=\mathrm{C} \\
\text { aromatic }\end{array}$ & $\begin{array}{l}\mathrm{N}=0 \\
\text { Sym. } \\
\text { Asym. }\end{array}$ \\
\hline $4 a$ & 3220 & 1666 & 1635 & 1566 & \\
\hline $4 \mathrm{~b}$ & $\begin{array}{l}3433 \\
3258\end{array}$ & $\begin{array}{l}1717 \\
1716\end{array}$ & $\begin{array}{l}1651 \\
1655\end{array}$ & $\begin{array}{l}1602 \\
1596\end{array}$ & \\
\hline $4 c$ & 3214 & 1716 & 1651 & 1596 & \\
\hline $4 d$ & $\begin{array}{l}3257 \\
3193\end{array}$ & $\begin{array}{l}1717 \\
1705\end{array}$ & $\begin{array}{l}1653 \\
1657\end{array}$ & $\begin{array}{l}1596 \\
1597\end{array}$ & \\
\hline $4 \mathrm{e}$ & 3217 & 1705 & 1655 & $\begin{array}{l}1549 \\
1606\end{array}$ & $\begin{array}{l}1367 \\
1549\end{array}$ \\
\hline $4 \mathrm{f}$ & 3216 & 1738 & 1641 & $\begin{array}{l}1600 \\
1590\end{array}$ & \\
\hline $4 g$ & 3270 & 1673 & 1641 & $\begin{array}{l}1598 \\
1558\end{array}$ & \\
\hline $4 \mathrm{~h}$ & 3264 & 1713 & 1668 & 1594 & \\
\hline $4 \mathrm{i}$ & 3367 & 1699 & 1652 & 1496 & $\begin{array}{l}1346 \\
1520\end{array}$ \\
\hline $4 \mathrm{j}$ & 3450 (br.OH) & 1733 & 1639 & $\begin{array}{l}1616 \\
1574\end{array}$ & \\
\hline
\end{tabular}


Table 8: The Chemical shift ${ }^{1}$ H-NMR data of some synthesized 4-thiazolidinone (4a-j )DMSO (d6).

\begin{tabular}{|c|c|c|c|c|}
\hline Compound & $\begin{array}{l}\boldsymbol{\delta} \mathbf{N}-\mathbf{H}_{\text {amide }} \\
\mathbf{p p m}(\mathbf{s}, \mathbf{1 H})\end{array}$ & $\begin{array}{l}\boldsymbol{\delta} \mathbf{C H}_{\text {aromatic }} \\
\mathbf{p p m}(\mathbf{m}, \mathbf{8 H})\end{array}$ & $\begin{array}{l}\boldsymbol{\delta} \\
\text { thiazolidinone } \\
\mathbf{p p m ( s , 1 H )}\end{array}$ & $\begin{array}{l}\boldsymbol{\delta} \mathbf{C H}_{\text {2 thiazolidinone }} \\
\mathbf{p p m ( d , 2 H )}\end{array}$ \\
\hline $4 \mathrm{a}$ & 12 & $7.3-8.4$ & 7.2 & $4.7(\mathrm{~s})$ \\
\hline $4 \mathrm{~b}$ & 10.6 & $7-8.4$ & 6 & $3.8-4.7$ \\
\cline { 2 - 5 } & 11 & $7-8.4$ & 6 & $3.9-4.2$ \\
\hline $4 \mathrm{~d}$ & 11 & $7.4-8.4$ & 6 & $3.3-4$ \\
\hline $4 \mathrm{e}$ & & $7.4-7.7$ & 6 & $4.7(\mathrm{~s})$ \\
\hline $4 \mathrm{f}$ & 12.2 & $7.6-8.5$ & 7.2 & $4-4.3$ \\
\hline $4 \mathrm{i}$ & 9.4 & $7-8.3$ & 7 & $4-4.4$ \\
\hline $4 \mathrm{j}$ & 8.3 & $7.8-8.2$ & 6.9 & \multicolumn{2}{c}{} \\
\hline
\end{tabular}

Table 9: Chemical Shift $(\delta \mathrm{ppm}){ }^{13} \mathrm{C}-\mathrm{NMR}$ data for some of 4-thiazolidinones $(4 \mathrm{a}-\mathrm{j})$. Solvent: DMSO d $_{6}$

\begin{tabular}{|c|c|c|c|c|c|c|c|}
\hline Compound & $\mathbf{C H}_{\mathbf{3}}$ & $\begin{array}{c}\mathbf{C}_{\mathbf{6}} \\
\text { thiazolidinon }\end{array}$ & $\begin{array}{c}\mathbf{C}_{\mathbf{5}} \\
\text { thiazolidinon }\end{array}$ & $\mathbf{C}_{\mathbf{1}}$ & $\mathbf{C}_{\mathbf{2}, \mathbf{2}^{-}}$ & $\mathbf{C}_{\mathbf{3 , 3}}$ & $\mathbf{C}_{\mathbf{4}}$ \\
\hline $4 \mathrm{~d}$ & & 29.7 & 61.3 & 134 & 129.2 & 130.1 & 137 \\
\hline $4 \mathrm{e}$ & 22.32 & 31.57 & 61.45 & 132,93 & 130.65 & 128.61 & 139.63 \\
\hline $4 \mathrm{f}$ & & 22.16 & 63 & 146 & 124.56 & 129.13 & 148.3 \\
\hline $4 \mathrm{~g}$ & 40 & 38.4 & 66.7 & 152 & 112.26 & 121.9 & 137 \\
\hline
\end{tabular}

\begin{tabular}{|c|c|c|c|c|c|c|}
\hline Compound & $\begin{array}{c}\mathbf{C}_{\mathbf{7}} \\
\mathbf{C = O}\end{array}$ & $\begin{array}{c}\mathbf{C}_{\mathbf{8}} \\
\mathbf{C =}=\mathbf{O}\end{array}$ & $\mathbf{C}_{\mathbf{9}}$ & $\mathbf{C}_{\mathbf{1 0 , 1 0}} \mathbf{-}^{-}$ & $\mathbf{C}_{\mathbf{1 1}, \mathbf{1 1}}$ & $\mathbf{C}_{\mathbf{1 2}}$ \\
\hline $4 \mathrm{~d}$ & 169.5 & 164.68 & 133.65 & 129 & 128.5 & 137.91 \\
\hline $4 \mathrm{e}$ & 169.54 & 167.7 & 134.56 & 131.35 & 128.5 & 141 \\
\hline $4 \mathrm{f}$ & 170 & 162 & 137 & 130.15 & 128.53 & 140.9 \\
\hline $4 \mathrm{~g}$ & 170 & 167 & 135 & 129.88 & 128.97 & 149 \\
\hline
\end{tabular}<smiles></smiles>

4d<smiles>CN(C)c1ccc(C2CCC(=O)N2NC(=O)c2ccc(Cl)cc2)cc1</smiles>

$4 g$

CONCLUSION

From the result of the reaction of acid hydrazones with thioglycolic acid, it has been showed that they are depended on the reaction medium (solvent), so the reaction in benzene has more effect than in ethanol. The times of the reactions also were affected by the type of substituent on the azomethines bond and this type of reactions can be done without using catalyst. 
$(+)$ The biological effect showed the activity of this type of thiazolidinone derivatives against the Grame-negative bacteria psedomonas aeruginosa is more than the Gram-positive one staphylococcus aureus.

\section{REFERENCES}

Abhinit, M.; Ghodke, M.; Pratima, N.A. (2009). Exploring potential of 4-thiazolidinone. International J. Pharmacy and Pharmaceutical Sci., Review article, 1, 47-64.

Ali, H.M. (2007). Synthesis and characterization studies of some metal complexes macroligands containing $\mathrm{S}$ and $\mathrm{N}$ atoms. Baghdad University Ibnil Haytham, (thesis).

Andres, C.J.; Bronson, J.J.; D’Andrea, S.V.; Deshpande, M.S.; Falk, P.J.; Grant-Young K.A.; Harte, W.E.; Ho H.-T.; Misco, P. F.; Robertson, J.G.; Stock, D.; Sun, Y.; Walsh, A.W. (2000). 4Thiazolidinones: novel inhibiters of the bacterial enzyme MurB. Bioorganic \& Medicinal Chemistry Letters, 10, 715-717.

Aydogan, F.; Ocal, N.; Turgut, Z.; Yolacan, C. (2001). Transformations of aldimines derived from pyrrol-2-carbaldehyde- synthesis of thiazsolidino-fused compounds. Bull. Korean Chem. Soc., 22, 5.

Jasim, I.K.; Karim, N.H.; Aumran, K.A. (2008).Preparation and characterization for some new derivatives of Schiff base compound and study of their biological activity. J. Diala, 31.

Küçükgüzel, G.; Kocatepe, A.; Clercq, E.D.; Fikrettin, G.M. (2006). Synthesis and biological activity of 4-thiazolidinones, thiosemicarbazides derived from diflunisal hydrazide. European J. Medicinal Chemistry,4,353-359.

Nagarajan, A.S.; Kamalraj, S.; Muthumary, J.; Reddy, B.S.R. (2009). Synthesis of biologically active benzothiazole substituted thiazolidinone derivatives via cyclization of unsymmetrical imines. Indian J. Chemistry, 48,1577-1582.

Palekar, V.S.; Amle, A.J.; Shukla, S.R. (2009). Synthesis and antibacterial activity of some novel bis-1,2,4-triazolo(3,4-b)-1,3,4-thiadiazoles and bis-4-thiazolidinone derivatives from terephthalic dihydrazide, European J. Medicinal Chemistry, 44, 5112-5116.

Patel, N.B.; Patel, S.D. (2010). Synthesis and invitrobial study of Schiff base and Thiazolidinone of 1-Cyclopropyl-6-flouro-7-[4-(2, 3)-dichloro phenyl) peprazin-1-yl]-4-qunoline. Acta poloniae Pharmaceutica -drug research, 67(1), 45-35.

Patel, N.B.; Shaikh, F.M. (2010). Synthesis of new pyridine based 4-thiazolidinones incorporated benzothiazoles and evaluation of their antimicrobial activity. J. Science, Islamic Rebublic of Iran, 21(2),121-129.

Patil, Sh.B.; Goudgaon, N.M. (2010). Synthesis of 3- (1-benzyl-1H-benzo (D) imidazol -2- (3-aryl1-phenyl-1H-pyrazol-4-yl) thiazolidin-4-ones and their antimicrobial activities, International journal of Pharmaceutical Sciences and Research, 1, 50-56.

Rao, A.; Chimirri, A.; Ferro, S.; Monforte, A.M.; Monforte, P.; Zappala, M. (2004). Microwaveassisted synthesis of benzimidazole and thiazolidinone derivatives as HIV-RT inhibiters, Arkivoc, V, 147-155.

Rawal, R.K.; Kumar, A. (2006). Molecular docking studies on 4-thiazolidinones as HIV-1 RT inhibitors. J. Mol. Model., 13(1), 155-161.

Rollas, S.; Küçükgüzel, G.Ş. (2007). Biological activities of hydrazone derivatives. Molecules, 12, 1910-1939.

Sanghani, A.M.; Sanja, D.B.; Rajani, V.R.; Godhani, R.D. (2008). Synthesis and biological activities of 4-oxo thiazolidinone derivatives. J. Indian Chem. Soc., 85, 557-560.

Sattigeri, V.J.; Soni, A.; Singhal, S.; Khan, S.; Pandya, M.; Bhateja, P.; Mathur, T.; Rattan, A.; Khanna, J.M.; Mehta, A. (2005). Synthesis and antimicrobial activity of novel thiazolidinones. Arkivoc, ii, 46-59.

Sha h, T.J.; Desia, V.A. (2007). Synthesis of some novel fluorinated 4-thiazolidinones containing amide linkages and their antimicrobial screening. Arkivoc, xiv, 218-228. 
Silver, L.L. (2003). Novel inhibiter of bacterial cell wall synthesis. Current Opinion in Microbiology, 6, 431-438.

Singh, S.P.; Parmar, S.S.; Raman, K.; Stenberg, V.I. (1981). Chemistry and biological activity of thiazolidinone. Chemical Review, 81(2), 175-202

Tatar, E. Küçükgüzel, I.; Clercq, E.D.; Şahin, F.; Güllüce, M. (2008). Synthesis, characterization and screening of antimicrobial, antituberculosis, antiviral and anticancer activity of novel 1,3-thiazolidine-4-ones derived from 1-(2-(benzpyl amimo)-4-(methylthio)butyryl)-4alkyl/arylalkyl thiosemicarbazides. Arkivoc, xiv,191-120.

Verna, A.; Saraf, S.K. (2008). 4-Thiazolidinone- a biologically active scaffold. European J. Medicinal Chemistry, 43,897-905.

Williamson, F. (1964). “Organic Experiments”. 3rd edn., D.C. Health and Company, USA, 126 p. 